This is a self-archived version of an original article. This version may differ from the original in pagination and typographic details.

Author(s): Karjaluoto, Heikki; Shaikh, Aijaz A.; Leppäniemi, Matti; Luomala, Roope

Title: Examining Consumers' Usage Intention of Contactless Payment Systems

Year: 2019

Version: Accepted version (Final draft)

Copyright: (c) Emerald Publishing Limited 2019

Rights: In Copyright

Rights url: http://rightsstatements.org/page//nC/1.0/?language=en

Please cite the original version:

Karjaluoto, H., Shaikh, A. A., Leppäniemi, M., \& Luomala, R. (2019). Examining Consumers' Usage Intention of Contactless Payment Systems. International Journal of Bank Marketing, 38(2), 332-351. https://doi.org/10.1108/IJBM-04-2019-0155 


\title{
Examining Consumers' Usage Intention of Contactless Payment Systems
}

\author{
Heikki Karjaluoto \\ heikki.karjaluoto@jyu.fi \\ Jyväskylä University School of Business and Economics \\ P.O. Box 35, FI-40014, University of Jyväskylä, Finland
}

Aijaz A. Shaikh*

aijaz.a.shaikh@jyu.fi

Jyväskylä University School of Business and Economics

P.O. Box 35, FI-40014 University of Jyväskylä, Finland

\section{Matti Leppäniemi}

matti.leppaniemi@jyu.fi

Jyväskylä University School of Business and Economics

P.O. Box 35, FI-40014, University of Jyväskylä, Finland

\section{Roope Luomala}

roope.luomala@gmail.com

Jyväskylä University School of Business and Economics P.O. Box 35, FI-40014, University of Jyväskylä, Finland

* Corresponding author

+358469516017 


\title{
Examining Consumers’ Usage Intention of Contactless Payment Systems
}

\begin{abstract}
Purpose: This study develops and tests a conceptual model that combines the modified Unified Theory of Acceptance and Use of Technology (UTAUT2) with a consumer brand engagement model to predict consumers' usage intentions toward contactless payment systems in a developed country.
\end{abstract}

Design/methodology/approach - We cooperated with a contactless payment service provider in Finland and reached out to 22,000 customers, resulting in 1,165 usable responses. The collected data were analyzed using structural equation modeling.

Findings - The study shows that the UTAUT2 and the consumer brand engagement model together explain approximately $70 \%$ of the variance in usage intention. Of the predictors, habit and consumers' overall satisfaction have the strongest influence on usage intentions. The model also confirms the positive relationship between intention and use.

Practical implications - Understanding the reasons for both the intention to use and the continued use of contactless payments is important for merchants, banks, and other service providers. This study shows which technology adoption factors drive both the intention and the use of contactless payments. The finding that intention is mainly driven by habit and overall satisfaction and not by hedonic reasons indicates that such behaviors are difficult to change.

Originality/value - This study is among the first to examine contactless payment usage in a developed market, where over half of all point-of-sale transactions are executed using contactless payment cards and/or cell phones.

Keywords Contactless payments, Near field communication, UTAUT2, Consumer brand engagement, Usage intention

Paper type Research paper

\section{Introduction}

Since the introduction of near-field communication (NFC) technology in 2002 (Coskun et al., 2013), retail payment methods have been revolutionized by making them more convenient and easier to use. "Contactless payment" is a term that is widely used to explain the phenomenon of making secure retail payments at any merchant outlet, such as via an NFCenabled payment card by holding the card close to the point-of-sale (POS) terminal (which carries the contactless wave symbol) without using the PIN code (Nordea Bank, 2019). NFC technology (where no Internet connection is required) allows customers to use their NFCenabled payment cards and smartphones for over-the-counter payments instead of dipping or swiping the card at the POS terminal, inserting the PIN code or paying with cash. Considering the relatively high risk of misuse and/or skimming of payment cards, banks and other service providers have allowed a maximum contactless payment limit of up to 50 euros per transaction. Other forms of contactless payments require the pre-loading of debit or credit card information onto an NFC-enabled cell phone. During the early days of contactless 
payment systems, the use of mobile phones required the attachment of an NFC sticker onto a mobile phone that lacked the NFC function.

Another form of payment method is called the remote payment method. As the name implies, unlike the contactless payment method, the remote payment method uses cellular networks (or WiFi); as such, it does not require proximity to the POS terminal.

Although contactless payments are easier, faster, and more convenient to use, research (Gerpott and Meinert, 2017; Haidong et al., 2019) has shown that the worldwide use of NFC is still in its early stages. In European countries, the market share varies greatly by country. Whereas in Hungary, Czechia, and Poland, the market share is over $80 \%$, in Germany and Belgium, it is only $14 \%$ and $4 \%$, respectively (Statista, 2019). Contactless payments via NFC may still be an uncomfortable option for cash or PIN payments for many due to increasing privacy and security issues (Khalilzadeh et al., 2017). For instance, in Finland (the context of this study), fears regarding security and trustworthiness, along with the old habit of using diversified forms of payment, are considered the main hindrances to using contactless payments (Finance Finland, 2019). Despite these challenges, NFC technology is spreading quickly to payment cards, cell phones, and contactless-enabled POS terminals. It seems that nothing will stop NFC from becoming the most popular and standard accepted method for small retail payment transactions globally.

This study augments the extent literature in several ways. For example, it contributes to the debate on innovative technologies, such as contactless payment systems adoption and use from the perceptive of business to consumer (B2C). Earlier explorations (Hampshire, 2017; Karjaluoto et al., 2019; Shaikh, Glavee-Geo, and Karjaluoto, 2018; Schierz et al., 2010) have focused on factors that affect intention to use mobile banking and mobile payment systems in general, and only a few have explored specific forms of digital payments, such as NFC-based contactless payments. In addition, to understand the usage of contactless payment systems, we build our model on two theoretical premises: We test the effects of core marketing constructs, namely perceived risk (PR), consumer brand engagement (CBE), brand commitment, and overall satisfaction, on continuous usage intention of contactless payment systems, and we build our model on the revised Venkatesh et al., (2012) Unified Theory of Acceptance and Use of Technology (UTAUT2) to obtain further insights regarding the variance of continuous usage intention. From the UTAUT2 model, we adopt performance expectancy (PE), effort expectancy (EE), hedonic motivation (HM), and habit as antecedents to continuous intention to use contactless payment systems.

In the remaining sections, we next briefly discuss the state of contactless payments in the study context, Finland. We then present the research model and the related hypotheses. This is followed by a discussion of our method and the results. This paper concludes with a discussion on the theoretical, practical, and societal implications and limitations of the study and consider future research directions.

\section{Contactless payments in Finland}

There has been a rapid growth of contactless payment systems and their usage in Finland since they launched in 2013. Per the Taxpayers Association of Finland (2019), over 500 million contactless payment transactions were performed in Finland during 2018 via payment cards (i.e., around half of all card transactions), which is in line with those of Europe, on average (Statista, 2019). Per Finance Finland (2019), almost all adults (18 years and older) in 
Finland possess a debit and/or credit card, and about 85\% of these cards are NFC-enabled (i.e., they contain a contactless payment option).

At present, about 93\% of Finnish adults who have the contactless payment option on their payment cards have used this option for executing retail transactions. A maximum limit of 25 euros was previously fixed by banks and other service providers for the use of contactless payment options. However, in April 2019, this limit was raised to 50 euros, which is expected to boost its use. The Taxpayers Association of Finland (2019) estimated that, in 2019, up to $70 \%$ of payment card transactions at POS terminals will be contactless payments. The main reasons for the rapid growth are that Finnish consumers are equipped with contactless payment enabled cards, and most merchants have updated their POS terminals to accept contactless payments. Using the contactless system speeds up the transaction for both the buyer and the seller because a PIN code is not required for purchases that are less than 50 euros.

\section{Research model and hypotheses}

The research model, which is presented in Figure 1, is divided into three sections. The first section - the Consumer Brand Engagement Model-comprises four latent variables, including PR, CBE, brand commitment, and overall satisfaction, which are all related to the user's evaluations of the contactless payment system service provider. The second part of the model, which is labelled UTAUT2, utilizes four UTAUT2 variables, including PE, EE, HM, and habit, to predict consumer intention to use contactless payment system. The third part of the model consists of the dependent variable continuous usage, which is measured by the behavioral intention to use and the actual use of the contactless payment system.

\section{[Insert Figure 1 about here]}

\subsection{The relationship between consumer brand engagement and consumer brand commitment} It is widely believed that examining consumer engagement (CE) in today's always-connected world is important (Kumar and Pansari, 2016; Venkatesan, 2017)), and consumer engagement with a brand or service has arguably been conceptually distinct from other closely related variables, such as commitment, satisfaction, involvement, and loyalty. Even though CE has long been under scientific examination in several disciplines, including social psychology and organizational behavior, the concept has only emerged in the marketing literature in the last few years (Brodie et al., 2011).

Prior studies (Hollebeek et al., 2014; Calder et al., 2009) have found that consumer engagement with a certain brand (i.e. CBE) positively influences organizational performance outcomes, such as increased profitability, cost reduction, and online advertising effectiveness. $\mathrm{CBE}$ refers to a "consumer's positively valenced brand-related cognitive, emotional, and behavioral activity during or related to focal consumer brand interactions" (Hollebeek et al., 2014, p. 149). CBE in the context of contactless payment system refers to a consumer's positively valenced brand-related cognitive, emotional, and behavioral activity, either during or related to focal consumer payment system interactions.

Commitment is widely considered a crucial psychological force that links the customer to the organization (Bilgihan et al., 2013). Prior research (e.g., Osuna Ramírez et al., 2017) has defined brand commitment as an enduring consumer desire to continue a relationship with a brand as well as the desire of a customer to maintain a valued and/or long-term relationship with a brand due to previous satisfactory interactions. Per Tseng et al., (2017), commitment to 
a brand occurs when consumers believe that maintaining an ongoing relationship with a brand provides greater functional and emotional benefits than could be reaped by ending it.

When a user has a strong engagement toward a firm or service provider, that person will be more committed to using the brands, products, services, and technologies that are offered by that service provider including banks. Sashi (2012) stated that CE requires the establishment of trust and commitment in buyer-seller relationships; therefore, a direct relationship between $\mathrm{CE}$ and commitment is found in the extent literature. In addition, CE towards either an organization, service or product has recently been related to commitment. For example, Vivek et al. (2012) proposed that higher levels of benefits result from CE with an organization's product, service and even offerings or activities, which tends to produce greater consumer brand commitment toward the firm. We thus posit the following:

H1: Consumer brand engagement has a positive relationship with consumer brand commitment

3.2. The relationship between consumer brand commitment and consumer overall satisfaction The effects of commitment on consumer behavior toward a certain product, brand, service, or organization, in general, have been widely examined (Shaikh et al., 2015; Sanchez-Franco, 2009). Prior research (Gundlach et al., 1995; Radzi et al., 2018) has highlighted the importance of commitment by stating that this variable is a significant ingredient of any successful long-term relationship, and that commitment is a potential driver of customer loyalty. Overall satisfaction, on the other hand, is a cumulative evaluation based on the total purchase and consumption experience of a product or service over time (Garbarino and Johnson, 1999) and is largely viewed as a function of all previous transaction-specific satisfactions (Jones and Suh, 2000).

Although previous research (Sanchez-Franco, 2009; Gundlach et al., 1995) has established a relationship between commitment and satisfaction, research into how consumer commitment affects overall satisfaction has been less than conclusive. To fill this gap, we have posited that, in the case of the contactless payment system, commitment is a driver of overall satisfaction of the consumer. Thus, we hypothesize the following:

H2: Consumer brand commitment has a positive relationship with consumer overall satisfaction.

\subsection{The relationships between perceived risk and consumer brand engagement (H1), consumer brand commitment (H3), and intention to use (H4)}

Perceived risk (PR) refers to uncertainty (Bauer, 1967) and the expectation of losses (Peter and Ryan, 1976) associated with using a product or service. Consequently, in the current study, PR is defined as the potential for loss in the pursuit of the desired outcome of using a contactless payment system (see Featherman and Pavlou, 2003). PR has been shown to negatively influence consumers' behavioral intentions across digital retail contexts (Marriott and Williams, 2018). Therefore, the key value proposition of contactless payments is to implement necessary protocols and procedures to ensure the safe execution of digital transactions without any security vulnerabilities.

In the context of our study, PR is likely to be present in several ways. For example, low-value transactions executed via contactless payment systems do not require personal identification number (PIN) authorization, and the payment instruments functioning via NFC is susceptible 
to theft and misuse. Nonetheless, in larger value payments, the PIN is required to authenticate and authorize the proximity payments. In addition, third parties may intercept data that are transmitted over contactless networks. Finally, NFC technology, as well as the newly enacted PSD2 directives, has drawn new companies to the finance sector, which means it will expand the scope of the payment business allowing the third parties to oversee payment traffic between consumers, banks, and retailers, yet they are not considered as trustworthy as traditional banks are. Because NFC is a fairly new payment technology, in addition to the risks listed above, numerous other forms of uncertainty and risks may arise in the near future.

In online or digital services, such as contactless payments, where personal and/or face-to-face contact with the service provider is either minimal or non-existent, CBE with the service provider demands high trust and low uncertainty and risk. Therefore, it is generally believed that high-risk perceptions distort CBE toward the technology and/or service provider. Although no empirical research, in our knowledge, to date has examined the effects of perceived risk on brand engagement in the context of contactless payments, a few researchers (Brodie et al., 2013; Nolan et al., 2007) have concluded that an individual engages in online business communities when the perceived risk is low. This implies that, as risk concerns increase, the consumer level of engagement with a product, service, and/or application will decrease. Thus, we hypothesize the following:

H3: Perceived risk has a negative relationship with customer brand engagement.

Investigating the connection between $\mathrm{PR}$ and commitment is significant within an innovative service domain, such as contactless payment system, which (a) does not require face-to-face interaction, (b) is more intangible, and (c) inherently carries high risk, including system and/or service failures. Consequent to this intangibility of services, most consumers perceive a higher risk with services than they do with goods (Rundle-Thiele and Bennett, 2001). Under these circumstances, achieving and maintaining a comfortable long-term relationship in the service context while controlling risks is becoming more daunting for marketers. This is even more intriguing in the risk-averse consumer segment, which, per Aldas-Manzano et al., (2011), feels threatened by ambiguous situations and is mostly reluctant to try new and emerging products/services, such as contactless payment system.

Few empirical studies have previously investigated the relationship between PR and consumer brand commitment. Of these few, Aldas-Manzano et al. (2011) found that increasing PR threatens customer loyalty, which is a construct that is closely related to commitment. Thus, we posit the following:

H4: Perceived risk has a negative relationship with consumer brand commitment.

Intention to use in this study refers to consumer intent to use contactless payment system in the near future. Knowing consumers' use intention is considered important for information scientists and marketing managers in making strategic decisions and forecasting sales of both their existing and their new products and services (Tsiotsou, 2006). The theory of PR suggests that, in a B2C context, risk perception will negatively affect willingness to perform a risky behavior (Nicolaou and McKnight, 2006). Consequent to the presence of a certain degree of uncertainty in electronic or online exchange of goods and services, risk perceptions negatively affect a consumer's intention to use a specific product or service. These arguments have been well supported in prior research. For example, Chao et al. (2016) found that PR negatively influences the behavioral intention to use search engines. Similarly, Chen (2013) found that 
PR negatively affects consumer attitudes and intention to use in the m-banking services context. Faqih (2013) reported that PR negatively influences the behavioral intention to use online shopping channels for purchases. Thus, we hypothesized the following:

H5: Perceived risk has a negative relationship with the intention to use.

\subsection{The relationship between consumer overall satisfaction and intention to use} While investigating the relationship between overall satisfaction and consumer intention, Tsiotsou (2006) found that consumer involvement, overall satisfaction, and perceived product quality can be used as predictors of purchase intentions. Similarly, Chen (2008) found that overall satisfaction has a direct influence on behavioral intention. In line with these findings, we posit the following:

H6: Consumer overall satisfaction has a positive relationship with the intention to use.

\subsection{The Unified Theory of Acceptance and Use of Technology (UTAUT and UTAUT2)} Venkatesh et al. (2003) introduced a unified theoretical model called UTAUT, which included four core variables for predicting intention and usage: performance expectancy (analogous to perceived usefulness), effort expectancy (analogous to perceived ease of use), social influence, and facilitation conditions. In addition, four moderators of these key relationships were also proposed: gender, age, experience, and voluntariness of use. The purpose of introducing UTAUT was to understand the usage of information systems as a dependent variable in an organizational context. Subsequently, Venkatesh et al. (2012) introduced the modified and extended UTAUT2 model. This revised model incorporates three additional constructs: hedonic motivation, price value, and habit. Unlike UTAUT, the UTAUT2 also included three moderators -age, gender, and experience - which were hypothesized to moderate the effects of the constructs on behavioral intention (Venkatesh et al., 2012).

UTAUT2, which has become well established in contemporary research, addresses the consumer context (Shaw and Sergueeva, 2019), where consumers adopt information systems, such as contactless payment systems, on their own. Research has applied the UTAUT2 to several contexts, such as m-commerce (Shaw and Sergueeva, 2019), social networking sites (Herrero and San Martín, 2017), and m-banking (Alalwan, Dwivedi, and Rana, 2017).

\subsubsection{The relationship between performance expectancy (H7) and effort expectancy (H8) with intention to use \\ $\mathrm{PE}$ is defined as "the degree to which an individual believes that using the system will help him or her to attain gains in job performance.” (Venkatesh et al., 2003, p. 447). PE is considered similar to five variables (Venkatesh et al., 2003): perceived usefulness, extrinsic motivation, job fit, relative advantage, and outcome expectations. PE has been considered a powerful tool for explaining the customers' intention to use a certain information system or application (Luo et al., 2010).}

In the context of contactless payments, the ease of use and rapidity of the payment process reduces the time taken to conduct a payment, which could be considered a clear benefit. Khalilzadeh et al. (2017) examined the determinants of NFC-based contactless payment system technology acceptance in the restaurant industry and found that utilitarian PE has a stronger impact on intention to use contactless payment system systems than hedonic PE does. Similarly, Morosan and DeFranco (2016) found that PE is the highest predictor of 
intention to use NFC-based contactless payment system in hotels. In the m-banking services adoption context, Oliveira et al. (2014) found that initial trust, PE, technology characteristics, and task-technology fit have a positive effect on behavioral intention to adopt. In addition, Herrero and San Martín (2017) found three major drivers of users' intention to use social network sites to publish content: PE, HM, and habit. In line with these findings, we posit the following:

H7: Performance expectancy has a positive relationship with the intention to use.

EE is defined as "the degree of ease associated with consumers' use of technology" (Venkatesh et al., 2012, p. 159). Like PE, EE is also developed from the variables of the existing models due to the similarities of the variable definitions. The variables include perceived ease of use (TAM/TAM2), complexity (IDT), and perceived self-efficacy (Venkatesh et al., 2003). Several studies have investigated the relationship between EE and intention to use information technology and systems, such as tablets (Magsamen-Conrad et al., 2015), m-banking (Alalwan et al., 2017), and mobile technologies (Oh et al., 2009).

Magsamen-Conrad et al. (2015) found that EE and facilitating conditions positively predict tablet use intentions. Alalwan et al. (2017) found that behavioral intention to use m-banking services is significantly and positively influenced by PE, EE, HM, price value, and trust. We therefore posit the following:

H8: Effort expectancy has a positive relationship with the intention to use.

\subsubsection{The relationship between hedonic motivation and intention to use}

Since the early 1990s, the information systems research has investigated and validated the acceptance and use of the information systems while embracing various theories such as the motivation theory, developed and proposed by Davis (1993). This theory broadly states that an individual, when engaging or interacting with an information system, considers two types of motivations: Intrinsic and Extrinsic. An intrinsic motivation, with emphasize on hedonic aspects, is obtained with the level of satisfaction, enjoyment, and fun from using an information system (Allam et al., 2019), performing an activity, or executing a transaction. Here, enjoyment and fun aspects of hedonic or intrinsic motivation are considered strong predictors of intention to use. Extrinsic motivation, on the other hand, is largely goal-driven and achieved in the expectations of achieving some monetary reward from performing an activity.

According to Brown and Venkatesh (2005) HM plays a pivotal role in new technology use and acceptance. HM directly affects technology acceptance and use (Van der Heijden, 2004). Moreover, Venkatesh et al. (2012) found that HM is a critical determinant of the behavioral intention to use technology. Per Sharif and Raza (2017), HM produces a positive, significant impact on behavioral intention to use internet banking. The nature of contactless payment system as one of the emerging technologies justifies the presence of both utilitarian and hedonic values; hence, we believe that HM positively impacts the intention to use contactless payment system technology and services. Based on the discussion above, we posit the following:

H9: Hedonic motivation has a positive relationship with the intention to use.

\subsubsection{The relationship between habit and intention to use}


Habit has been considered different from behavior, and has been primarily and extensively studied in the social psychology discipline (Bhatnagar and Papatla, 2019; Limayem et al., 2007). Habit refers to the frequency of past behavior (Ajzen, 1991), a nonconscious activation (Bargh and Gollwitzer, 1994), a non-reflective, repetitive behavior (Lindbladh and Lyttkens, 2002), and the most effective form of trust (Chiu, Hsu, Lai, \& Chang, 2012). Specifically, Limayem et al. (2007, p. 705) defined habit in the context of information system (IS) as the 'extent to which people tend to perform behaviors, such as using IS, automatically because of learning.'

The role of habit in predicting consumer usage behavior has been discussed in several previous studies (Hsiao et al., 2016; Chiu et al., 2012; Venkatesh et al., 2012). Shiau and Luo (2013) argued that the role of consumer habits is not that of an automatic behavior to specific situations; rather, it is an antecedent of behavioral intentions to increase the continuance of existing behavior. While suggesting the UTAUT2 model, Venkatesh et al. (2012) proposed and validated the relationship between habit and intention to use. Similarly, Morosan and DeFranco (2016) used the UTAUT2 model to examine the use of NFC m-payments and found a direct correlation between habit and intention to use NFC m-payments in hotels. Thus, we propose that habit is a significant driver of intention to use; as such, we hypothesize the following:

H10: Habit has a positive relationship with the intention to use.

\subsection{The relationship between intention to use and actual usage}

The role of intention as a predictor of consumer behavior is well established in prior research (Glavee-Geo et al., 2017; Ajzen, 1991). Ajzen (1985), in his widely known Theory of Planned Behavior, suggested that behavioral intention is the most significant predictor of a consumer's actual behavior. Extant literature (Thakur and Srivastava, 2014; Venkatesh et al., 2012) has shown that behavioral intention correlates with actual behavior; therefore, measuring intention will provide an acceptable indication of consumer behavior. Turner et al. (2010) conducted a systematic literature review involving 79 empirical studies regarding how TAM predicts the usage of information systems. Their results show that the behavioral intention to use is positively correlated with the actual usage of the information system. Another important finding in the consumer context was reported by Venkatesh et al. (2012), who conducted an online survey of 1,512 mobile Internet consumers. They found a significant relationship between behavioral intention and actual usage of the technology, which implies that usage follows consumers' intention to use technology. Based on this evidence, we posit the following:

H11: Intention to use has a positive relationship with actual usage.

\section{Methodology}

All the scales that were used to measure the study variables were derived from prior studies as follows: perceived risk (Featherman and Pavlou, 2003), brand engagement (Hollebeek et al., 2014), brand commitment (Keiningham et al., 2015), overall satisfaction (Mittal and Frennea, 2010), and performance expectancy, effort expectancy, hedonic motivation, habit, intention to use, and use (Venkatesh et al., 2012). Table 2 lists all the items and their measurements.

In collecting the data, we cooperated with contactless payment service provider in Finland and sent a survey link to 22,000 of their customers. The survey link explained the background and purpose of the study (i.e., contactless payments) and contained a lottery. The survey link 
was open for one week, and 1,165 responses were obtained, making the response rate of $5.2 \%$.

To assess nonresponse bias, we compared the first 200 respondents to the last 200 respondents. No statistically significant differences were found. Thus, nonresponse bias was unlikely. To minimize any common method variance, the respondents remained anonymous, and the items were mixed in the questionnaire.

The hypotheses were tested using the SmartPLS 3.2.7 (Ringle et al., 2015). The PLS-SEM was a suitable choice because this study focused on prediction, was exploratory in a broad sense, used formative indicators, and many of the variables did not follow a normal distribution pattern (Hair et al., 2017, p. 23).

\section{Results}

A total of $71.2 \%$ of the respondents were male. Regarding age, around half (55.4\%) the respondents were between 36 and 50 years old. Around one-fifth (21.7\%) were between 51 and 65 years old. The remaining were either between 18 and 35 (15.9\%) or over 66 years of age (7\%).

\subsection{Measurement model}

The measurement model's (Table 1 ) composite reliabilities were all high (>0.71) and had AVE values higher than 0.5 . In addition, the factor loadings were significant and higher than 0.51 (see Table 2). Discriminant validity was achieved; all the square roots of the AVE values exceeded the correlations of the other variables, and the HTMT ratios were all below the threshold of 0.90 (Henseler et al., 2015). The model's predictive relevance was high for brand commitment $\left(R^{2}=0.665\right)$ and intention to use $\left(R^{2}=0.698\right)$. For overall satisfaction, the $R^{2}$ value was 0.339. The CBE construct was modeled as a reflective-formative second-order construct. Due to the high multicollinearity (VIF > 5), one item measuring behavioral CBE ("X (Contactless Payment System brand) is one of the brands I usually use when I use [a] contactless payment system") was dropped from this construct. The outcome variable "use" was measured as a formative construct. The formative constructs met the criteria that were set in the literature; all the VIF values were below 5, and all the indicator outer weights and outer loadings were significant (Hair et al., 2017). In summary, the measurement model meets the criteria that were set in the literature (Hair et al., 2017).

[Insert Table 1 about here]

[Insert Table 2 about here]

\subsection{Structural model}

The results of the hypotheses' tests are shown in Table 3 and Figure 2.

[Insert Table 3 about here]

[Insert Figure 2 about here]

The first hypothesis proposes that CBE has positive effects on brand commitment, and this theory is supported by our results $(\beta=0.781, p<0.01)$. Thus, $\mathrm{H} 1$ is accepted. The results also confirm H2, which proposes a brand commitment to explain overall satisfaction $(\beta=0.583, p$ $<0.01)$. H3 proposes that PR is negatively related to CBE. In our study, PR has a significant negative effect on CBE $(\beta=-0.216, p<0.01)$, confirming H3. H4 proposed that PR is 
negatively related to brand commitment. The path coefficient of -0.119 is significant $(p<$ 0.01); thus, the hypothesis is also accepted. PR also explained intention to use (H5): the higher the risk, the less the intention to use $(\beta=-0.097, p<0.01)$. H6, which states that overall satisfaction has a positive effect on intention to use $(\beta=0.283, p<0.01)$, is also confirmed. Three of the four UTAUT2-based hypotheses are supported by the data: PE ( $\beta=$ $0.172, p<0.01)$, $\mathrm{EE}(\beta=0.106, p<0.01)$, and habit $(\beta=0.369, p<0.01)$ exhibited positive effects on intention to use, whereas the effect of HM on intention to use was not significant. Thus, we accept H7, H8, and H10, and reject H9. Finally, intention to use explained use is significant $(\beta=0.330, p<0.01)$, thereby supporting $\mathrm{H} 11$.

Of the control variables, gender had a small but significant effect on the intention to use $(\beta=$ $0.071, p<0.01$ ) but not on use, indicating that female users have a slightly higher intention to use. Age did not affect the intention to use, but it had a small yet significant positive effect on use $(\beta=-0.133, p<0.01)$. This indicates that the older the users are, the more they use the contactless payment function.

\section{Discussion and Implications}

This study examined the consumer usage intention of the contactless payment system in a developed country context. Using a consumer brand engagement model and a modified UTAUT2, 11 hypotheses were developed and tested.

\subsection{Theoretical implications}

This study presents a unique model that highlights both the intention to use and the actual usage of contactless payment systems in Finland. This study contributes to the prior literature by combining UTAUT2 and a consumer brand engagement model to explain the adoption of the contactless payment system. In prior literature, some studies have validated the CE and UTAUT models in the context of m-payments and m-banking (Khalilzadeh et al., 2017; Hepola et al., 2016; Zhou et al., 2010); however, to the best of our knowledge, our study is the first to empirically combine and evaluate CE and modified UTAUT models within the context of contactless payment systems' users.

It is widely believed that PR is a relevant factor in determining the use of mobile-based payment systems and that it represents a potential direct counterbalance to CE, commitment, and intention to use (Hepola et al., 2016; Chen 2013). Our findings suggest a stronger negative relationship between PR and CE and brand commitment compared to PR and intention to use contactless payment system. This may have occurred because the research participants consisted mainly of experienced customers who have used contactless payment system in their everyday life and have thus developed some level of trust in and experience with the technology.

In the contactless payment system context, we found that CBE had a positive effect on brand commitment. This result confirms that commitment is a significant consequence of CE (Abdul-Ghani et al., 2019; Brodie et al., 2011). The model also showed that perceived risk has a negative influence on CBE. This negative relationship between perceived risk and CBE implies that an insecure contactless payment system would damage the brand engagement and may trigger the switching behavior.

Our findings support the view that brand commitment has a strong relationship with overall satisfaction. The relationship in the information systems and marketing literature has considered customer overall satisfaction and commitment as two important predictors of 
retention (Gustafsson et al., 2005); therefore, their relationship is considered logical, and it was notably endorsed by Gundlach et al. (1995). This study also establishes a direct relationship between customer overall satisfaction and intention to use contactless payment system — a finding that was endorsed by Phonthanukitithaworn and Sellitto (2017) in the social media context.

In line with the UTAUT2 theory, our findings show that PE, EE, and habit have positive effects on intention to use, whereas the effect of HM on intention was not supported. The positive effects that were found have also been confirmed by other studies in the context of m-banking and remote m-payment systems (Slade et al., 2015; Venkatesh et al., 2012; Zhou et al., 2010). Although Brown and Venkatesh (2005) claimed that HM plays a pivotal role in new technology use, our findings did not confirm these effects. This is perhaps because payment transactions are largely considered utilitarian applications that provide instrumental value to consumers. Regarding habit, we add to the literature by confirming the positive effects of habit on intention (Venkatesh et al., 2012). Finally, the findings support the positive effects of intention to use on actual use, which in turn confirms the UTAUT2 findings that intention and use have a positive relationship (Venkatesh et al., 2012).

\subsection{Managerial and societal implications}

This study provides important user perspectives, which the industry should consider when deploying as well as promoting the contactless payment culture among various segments of society. In general, it is widely recognized in marketing and information systems research that, beyond technology and business aspects, users' views on information and communication technology adoption and usage are key determinants for the eventual success of any information system or technology (Cocosila and Trabelsi, 2016; Venkatesh et al., 2002).

Contactless payments can now be considered as a breakthrough in Finland and many other developed countries. Given the convenience and speed of using contactless payments systems, they have proven beneficial for the supply side, such as for grocery merchants and restaurants to avoid queues. It is no surprise that using contactless payments has become a habit for many consumers for this reason.

As reported in commercial research (Finance Finland 2019), this study draws the attention of the industry toward the growing risks that are involved in contactless payments. It is wellestablished that the perceived risk of losing confidential data as well as growing card skimming attacks on POS terminals are detractors to the adoption and usage process (GlaveeGeo et al., 2017), and the same has also been observed with the contactless payment system. The increasing risks with contactless payment system can damage CBE, brand commitment, and intention to use, which may lead to discontinuation of contactless payment technology use by today's well-informed and always-connected consumers. For managers, it is important to understand that consumers tend to gauge payment and banking businesses on their ability to manage risk both efficiently and effectively. Therefore, risk management is highly pertinent in financial transactions that are executed via various channels and devices. The one-size-fits-all or piecemeal approach to risk management will not work in these situations; consequently, banks and other service providers should focus on both the security and the reliability of contactless payment transactions. Security and privacy issues should be addressed first when designing strategies for the development and deployment of new payment platforms, services, and technologies. 
Unlike some previous studies (e.g., Church et al., 2017; Kivetz and Zheng, 2017), in which a strong focus was placed on providing hedonic value in payment applications and social media sites to develop consumer interest and retention, this study emphasizes PE, EE, overall satisfaction and most notably habit, regarding contactless payment system.

The societal implications of this study include offering immense convenience and instant connectivity of consumers to their financial information system via NFC-enabled payment cards and downloadable mobile payment applications containing payment card information. Contactless payment systems bring the remote and financially excluded consumer segment into the formal payment system as well as promote savings. Per the World Bank (2018), over 1.7 billion adults remain outside the banking mainstream. In addition, more than 40 million of these unbanked adults live in European Union member countries that have either little or no access to digital payment systems. Contactless payment systems have created an affordable payment infrastructure for banks and consumers, increased financial inclusion, and started the trend of building cashless societies.

\subsection{Limitations and future research directions}

Our research is not without any limitations. First, our study is cross-sectional in nature, which limits the controllability of unobserved heterogeneity. Thus, future research should test our theoretical model using experiments and/or longitudinal studies to tease out these potential effects. Second, because the concept of the contactless payment system is fairly new, is deployed in most developing economies, and technology development is rapidly progressing, our research is a snapshot of contactless payment systems in the current business environment and the context of a developed country. Therefore, future studies should explore the adoption of contactless payment systems by using international samples, which should preferably be collected from emerging and developing countries. Third, because of the emergence as well as the proliferation of other portable devices, such as smart watches, smart wristbands, fobs, stickers, and even contactless coats (De Kerviler et al., 2016), future research should consider these and examine their effect on the adoption and usage behavior of consumers in the contactless payment context. Fourth, like numerous previous technology acceptance studies, our research has built its theoretical foundation partly on the initial TAM (Davis, 1989). Although the TAM and its extended versions are proven models, performing qualitative research on the adoption of contactless payment system could provide deeper insights into factors that affect the use of contactless payments and m-payments in general. Finally, additional constructs might be added to the research model, and tests of indirect effects might be included in future research works.

\section{References}

Abdul-Ghani, E., Hyde, K. F. and Marshall, R. (2019), “Conceptualising engagement in a consumer-to-consumer context”, Australasian Marketing Journal (AMJ), Vol. 27 No. 1, pp. 2-13.

Ajzen, I. (1985), “From intentions to actions: a Theory of Planned Behavior”, in Kuhl, J. \& Beckmann, J. (Eds.), Action Control. From Cognition to Behavior, Springer, Berlin Heidelberg, pp. 11-39.

Ajzen, I. (1991), “The Theory of Planned Behavior”, Organizational Behavior and Human Decision Processes, Vol. 50 No. 2, pp. 179-211. 
Alalwan, A. A., Dwivedi, Y. K. and Rana, N. P. (2017), "Factors influencing adoption of mobile banking by Jordanian bank customers: Extending UTAUT2 with trust”, International Journal of Information Management, Vol. 37 No. 3, pp. 99-110.

Aldas-Manzano, J., Ruiz-Mafe, C., Sanz-Blas, S. and Lassala-Navarre, C. (2011), “Internet banking loyalty: evaluating the role of trust, satisfaction, perceived risk and frequency of use”, The Service Industries Journal, Vol. 31 No. 7, pp. 1165-1190.

Allam, H., Bliemel, M., Spiteri, L., Blustein, J. and Ali-Hassan, H. (2019), “Applying a multidimensional hedonic concept of intrinsic motivation on social tagging tools: A theoretical model and empirical validation”, International Journal of Information Management, Vol. 45, pp. 211-222.

Bargh, J. A. and Gollwitzer, P. M. (1994), "Environmental control of goal-directed action: Automatic and strategic contingencies between situations and behavior”, In W. D. Spaulding (Ed.), Nebraska Symposium on Motivation, Vol. 41. Integrative Views of Motivation, Cognition, and Emotion, University of Nebraska Press, Lincoln, NE, US, pp. 71-124.

Bhatnagar, A. and Papatla, P. (2019), "Do habits influence the types of information that smartphone shoppers seek?”, Journal of Business Research, Vol. 94, pp. 89-98.

Bilgihan, A., Okumus, F. and Cobanoglu, C. (2013), “Generation Y travelers’ commitment to online social network websites”, Tourism Management, Vol. 35, pp. 13-22.

Brodie, R.J., Hollebeek, L.D., Juric, B. and Ilic, A. (2011), “Customer engagement: conceptual domain, fundamental propositions, and implications for research”, Journal of Service Research, Vol. 14 No. 3, pp. 252-271.

Brodie, R. J., Ilic, A., Juric, B. and Hollebeek, L. (2013), “Consumer engagement in a virtual brand community: An exploratory analysis”, Journal of Business Research, Vol. 66 No. 1, pp. 105-114.

Brown, S. A. and Venkatesh, V. (2005), "Model of adoption of technology in households: A baseline model test and extension incorporating household life cycle”, MIS Quarterly, Vol. 29 No. 3, pp. 399-426.

Calder, B. J., Malthouse, E. C. and Schaedel, U. (2009), “An experimental study of the relationship between online engagement and advertising effectiveness", Journal of Interactive Marketing, Vol 23 No. 4, pp. 321-331.

Chao, C. Y., Chang, T. C., Wu, H. C., Lin, Y. S. and Chen, P. C. (2016), “The interrelationship between intelligent agents' characteristics and users' intention in a search engine by making beliefs and perceived risks mediators”, Computers in Human Behavior, Vol. 64, pp. 117-125.

Chen, C. (2013), “Perceived risk, usage frequency of mobile banking services”, Managing Service Quality, Vol. 23 No. 5, pp. 410-436. 
Chen, C. F. (2008), "Investigating structural relationships between service quality, perceived value, satisfaction, and behavioral intentions for air passengers: Evidence from Taiwan”, Transportation Research Part A: Policy and Practice, Vol. 42 No. 4, pp. 709-717.

Chiu, C. M., Hsu, M. H., Lai, H. and Chang, C. M. (2012), "Re-examining the influence of trust on online repeat purchase intention: The moderating role of habit and its antecedents", Decision Support Systems, Vol. 53 No. 4, pp. 835-845.

Church, E. M., Thambusamy, R. and Nemati, H. (2017), "Privacy and pleasure: A paradox of the hedonic use of computer-mediated social networks", Computers in Human Behavior, Vol. 77, pp. 121-131.

Coskun, V., Ozdenizci, B. and Ok, K. (2013), “A survey on near field communication (NFC) technology”, Wireless Personal Communications, Vo. 71 No. 3, pp. 2259-2294.

Cocosila, M. and Trabelsi, H. (2016), “An integrated value-risk investigation of contactless mobile payments adoption”, Electronic Commerce Research and Applications, Vol. 20, pp. 159-170.

Davis, F. D. (1989), "Perceived usefulness, perceived ease of use, and user acceptance of information technology”, MIS Quarterly, Vol. 13 No. 3, pp. 319-340.

Davis, F. (1993), "User acceptance of information technology: System characteristics, user perceptions and behavioral impacts”, International Journal of Man-Machine Studies, Vol. 38 No. 3, pp. 475-487.

De Kerviler, G., Demoulin, N. T. and Zidda, P. (2016), “Adoption of in-store mobile payment: Are perceived risk and convenience the only drivers? Journal of Retailing and Consumer Services, Vol. 31, pp. 334-344.

Faqih, K. M. (2013), "Exploring the influence of perceived risk and internet self-efficacy on consumer online shopping intentions: Perspective of technology acceptance model”, International Management Review, Vol. 9 No. 1, pp. 67-77.

Featherman, M. S. and Pavlou, P. A. (2003), "Predicting e-services adoption: a perceived risk facets perspective”, International Journal of Human-Computer Studies, Vol. 59 No. 4, pp. 451-474.

Finance Finland (2019), “Saving, borrowing and payment methods” (translated), Report, available at: http://www.finanssiala.fi/materiaalit/SLM\%202019_Tutkimusraportti.pdf (accessed 5 August 2019).

Garbarino, E. and Johnson, M. S. (1999), "The different roles of satisfaction, trust, and commitment in customer relationships”, Journal of Marketing, Vol. 63 No. 2, pp. 70-87.

Gerpott, T. J. and Meinert, P. (2017), "Who signs up for NFC mobile payment services? Mobile network operator subscribers in Germany", Electronic Commerce Research and Applications, Vol. 23, pp. 1-13. 
Glavee-Geo, R., Shaikh, A. A. and Karjaluoto, H. (2017), "Mobile banking services adoption in Pakistan: are there gender differences?” International Journal of Bank Marketing, Vol. 35 No. 7, pp. 1090-1114.

Gundlach, G. T., Achrol, R. S. and Mentzer, J. T. (1995), “The structure of commitment in exchange”, Journal of Marketing, Vol. 59 No. 1, pp. 78-92.

Gustafsson, A., Johnson, M. D. and Roos, I. (2005), “The effects of customer satisfaction, relationship commitment dimensions, and triggers on customer retention”, Journal of Marketing, Vol. 69 No. 4, pp. 210-218.

Hair, J. F. Jr., Hult, G. T. M., Ringle, C. M. and Sarstedt, M. (2017), A Primer on Partial Least Squares Structural Equation Modeling (PLS-SEM), $2^{\text {nd }}$ ed., Sage, Thousand Oaks, California.

Hampshire, C. (2017), “A mixed methods empirical exploration of UK consumer perceptions of trust, risk and usefulness of mobile payments”, International Journal of Bank Marketing, Vol. 35 No. 3, pp. 354-369.

Henseler, J., Ringle, C. M. and Sarstedt, M. (2015), “A new criterion for assessing discriminant validity in variance-based structural equation modeling”, Journal of the Academy of Marketing Science, Vol. 43 No. 1, pp. 115-135.

Hepola, J., Karjaluoto, H. and Shaikh, A. A. (2016), ”Consumer engagement and behavioral intention toward continuous use of innovative mobile banking applications: A case study of Finland”, In ICIS 2016: Proceedings the Thirty Seventh International Conference on Information Systems. Digital Innovation at the Crossroads, Dublin, Ireland, 2016, Curran Associates, Inc., NY, Association for Information Systems (AIS), pp. 1-20.

Herrero, Á. and San Martín, H. (2017), "Explaining the adoption of social networks sites for sharing user-generated content: A revision of the UTAUT2", Computers in Human Behavior, Vol. 71, pp. 209-217.

Hollebeek, L. D., Glynn, M. S. and Brodie, R. J. (2014), “Consumer brand engagement in social media: Conceptualization, scale development and validation”, Journal of Interactive Marketing, Vol. 28 No. 2, pp. 149-165.

Hsiao, C. H., Chang, J. J. and Tang, K. Y. (2016), “Exploring the influential factors in continuance usage of mobile social Apps: Satisfaction, habit, and customer value perspectives”, Telematics and Informatics, Vol. 33 No. 2, pp. 342-355.

Jones, M. A. and Suh, J. (2000), “Transaction-specific satisfaction and overall satisfaction: an empirical analysis, “Journal of Services Marketing, Vol. 14 No. 2, pp. 147-159.

Karjaluoto, H., Shaikh, A. A., Saarijärvi, H. and Saraniemi, S. (2019), "How perceived value drives the use of mobile financial services apps", International Journal of Information Management, Vol. 47 No. 4, pp. 252-261. 
Keiningham, T. L., Frennea, C. M., Aksoy, L., Buoye, A. and Mittal, V. (2015), “A fivecomponent customer commitment model: implications for repurchase intentions in goods and services industries”, Journal of Service Research, Vol. 18 No. 4, pp. 433-450.

Khalilzadeh, J., Ozturk, A. B. and Bilgihan, A. (2017), "Security-related factors in extended UTAUT model for NFC based mobile payment in the restaurant industry", Computers in Human Behavior, Vol. 70, pp. 460-474.

Kivetz, R. and Zheng, Y. (2017), "The effects of promotions on hedonic versus utilitarian purchases”, Journal of Consumer Psychology, Vol. 27 No. 1, pp. 59-68.

Limayem, M., Hirt, S. G. and Cheung, C. M. (2007), "How habit limits the predictive power of intention: the case of information systems continuance”, MIS Quarterly, Vol. 31 No. 4, pp. 705-737.

Lindbladh, E. and Lyttkens, C. H. (2002), "Habit versus choice: the process of decisionmaking in health-related behavior”, Social Science \& Medicine, Vol. 55 No. 3, pp. 451-465.

Luo, X., Li, H., Zhang, J. and Shim, J. P. (2010), “Examining multi-dimensional trust and multi-faceted risk in initial acceptance of emerging technologies: An empirical study of mobile banking services”, Decision Support Systems, Vol. 49 No. 2, pp. 222-234.

Magsamen-Conrad, K., Upadhyaya, S., Joa, C. Y. and Dowd, J. (2015), “Bridging the divide: Using UTAUT to predict multigenerational tablet adoption practices", Computers in Human Behavior, Vol. 50, pp. 186-196.

Marriott, H. R. and Williams, M. D. (2018), “Exploring consumers perceived risk and trust for mobile shopping: A theoretical framework and empirical study”, Journal of Retailing and Consumer Services, Vol. 42, pp. 133-146.

Mittal, V. and Frennea, C. (2010), "Customer satisfaction: a strategic review and guidelines for managers”, MSI Fast Forward Series, Marketing Science Institute, Cambridge, MA.

Morosan, C. and DeFranco, A. (2016), “It's about time: Revisiting UTAUT2 to examine consumers' intentions to use NFC mobile payments in hotels”, International Journal of Hospitality Management, Vol. 53, pp. 17-29.

Nicolaou, A. I. and McKnight, D. H. (2006), "Perceived information quality in data exchanges: Effects on risk, trust, and intention to use”, Information Systems Research, Vol. 17 No. 4, pp. 332-351.

Nolan, T., Brizland, R. and Macaulay, L. (2007), "Individual trust and development of online business communities”, Information Technology \& People, Vol. 20 No. 1, pp. 53-71.

Nordea Bank (2019), “Contactless Payment”, available at: https://www.nordea.fi/en/personal/our-services/credit-payment-cards/contactlesspayment.html (accessed 10 August 2019) 
Oh, S., Lehto, X. Y. and Park, J. (2009), “Travelers' intent to use mobile technologies as a function of effort and performance expectancy”, Journal of Hospitality Marketing \& Management, Vol. 18 No. 8, pp. 765-781.

Oliveira, T., Faria, M., Thomas, M. A. and Popovič, A. (2014), "Extending the understanding of mobile banking adoption: When UTAUT meets TTF and ITM”, International Journal of Information Management, Vol. 34 No. 5, pp. 689-703.

Osuna Ramírez, S. A., Veloutsou, C. and Morgan-Thomas, A. (2017), “A systematic literature review of brand commitment: definitions, perspectives and dimensions", Athens Journal of Business and Economics, Vol. 3 No. 3, pp. 305-332.

Peter, J. P. and Ryan, M. J. (1976), “An investigation of perceived risk at the brand level”, Journal of Marketing Research, Vol 13 No. 2, pp. 184-188.

Phonthanukitithaworn, C. and Sellitto, C. (2017), "Facebook as a second screen: An influence on sport consumer satisfaction and behavioral intention”, Telematics and Informatics, Vol. 34 No. 8, pp. 1477-1487.

Radzi, N. A. A., Harun, A., Ramayah, T., Kassim, A. W. M. and Lily, J. (2018), "Benefits of Facebook fan/brand page marketing and its influence on relationship commitment among generation Y: empirical evidence from Malaysia”, Telematics and Informatics, Vol. 35 No. 7, pp. 1980-1993.

Ringle, C.M., Wende, S., and Becker, J.-M. (2015), “SmartPLS 3. Boenningstedt: SmartPLS GmbH”, available at: http://www.smartpls.com (accessed 10 November, 2018).

Rundle-Thiele, S. and Bennett, R. (2001), “A brand for all seasons? A discussion of brand loyalty approaches and their applicability for different markets”, Journal of Product \& Brand Management, Vol. 10 No. 1, pp. 25-37.

Sanchez-Franco, M. J. (2009), "The moderating effects of involvement on the relationships between satisfaction, trust and commitment in e-banking”, Journal of Interactive Marketing, Vol. 23 No. 3, pp. 247-258.

Sashi, C. M. (2012), “Customer engagement, buyer-seller relationships, and social media”, Management Decision, Vol. 50 No. 2, pp. 253-272.

Schierz, P. G., Schilke, O. and Wirtz, B. W. (2010), "Understanding consumer acceptance of mobile payment services: An empirical analysis", Electronic Commerce Research and Applications, Vol. 9 No. 3, pp. 209-216.

Shaikh, A. A., Glavee-Geo, R. and Karjaluoto, H. (2018), "How relevant are risk perceptions, effort, and performance expectancy in mobile banking adoption?” International Journal of EBusiness Research, Vol. 14 No. 2, pp. 39-60.

Shaikh, A. A., Karjaluoto, H. and Chinje, N. B. (2015), “Continuous mobile banking usage and relationship commitment-A multi-country assessment”, Journal of Financial Services Marketing, Vol. 20 No. 3, pp. 208-219. 
Sharif, A. and Raza, S. A. (2017), "The influence of hedonic motivation, self-efficacy, trust and habit on adoption of internet banking: a case of developing country", International Journal of Electronic Customer Relationship Management, Vol. 11 No. 1, pp. 1-22.

Shaw, N. and Sergueeva, K. (2019), “The non-monetary benefits of mobile commerce: Extending UTAUT2 with perceived value”, International Journal of Information Management, Vol. 45, pp. 44-55.

Shiau, W. L. and Luo, M. M. (2013), "Continuance intention of blog users: the impact of perceived enjoyment, habit, user involvement and blogging time”, Behaviour \& Information Technology, Vol. 32 No. 6, pp. 570-583.

Slade, E. L., Dwivedi, Y. K., Piercy, N. C. and Williams, M. D. (2015), “Modeling consumers' adoption intentions of remote mobile payments in the United Kingdom: extending UTAUT with innovativeness, risk, and trust”, Psychology \& Marketing, Vol. 32 No. 8, pp. 860-873.

Statista (2019), "Share of contactless payment transactions at POS (points of sale) in selected countries in Europe in 2018”, available at:

https:/www.statista.com/statistics/946228/contactless-payments-market-share-at-pos-ineurope-by-country/ (accessed 18 August, 2019)

Thakur, R. and Srivastava, M. (2014), “Adoption readiness, personal innovativeness, perceived risk and usage intention across customer groups for mobile payment services in India”, Internet Research, Vol. 24 No. 3, pp. 369-392.

The Taxpayers Association of Finland (2019). "Contactless payments become mainstream by doing so you ensure it is safe" (translated), Taloustaito, available at:

https://www.taloustaito.fi/Rahat/lahimaksaminen-valtavirtaistuu--nain-varmistat-etta-se-onturvallista/ (accessed 10 August, 2019)

Tseng, T. H., Huang, H. H. and Setiawan, A. (2017), "How do motivations for commitment in online brand communities evolve? The distinction between knowledge-and entertainmentseeking motivations”, Computers in Human Behavior, Vol. 77, pp. 326-335.

Tsiotsou, R. (2006), "The role of perceived product quality and overall satisfaction on purchase intentions”, International Journal of Consumer Studies, Vol. 30 No. 2, pp. 207-217.

Turner, M., Kitchenham, B., Brereton, P., Charters, S. and Budgen, D. (2010), “Does the technology acceptance model predict actual use? A systematic literature review”, Information and Software Technology, Vol. 52 No. 5, pp. 463-479.

Van der Heijden, H. (2004), "User acceptance of hedonic information systems”, MIS Quarterly, Vol. 28 No. 4, pp. 695-704.

Venkatesh, V., Morris, M. G., Davis, G. B. and Davis, F. D. (2003), "User acceptance of information technology: Toward a unified view”, MIS Quarterly, Vol. 27 No. 3, pp. 425-478. 
Venkatesh, V., Speier, C. and Morris, M.G. (2002), "User acceptance enablers in individual decision making about technology: Toward an integrated model”, Decision Sciences, Vol. 33 No. 2, pp. 297-316.

Venkatesh, V., Thong, J. Y. and Xu, X. (2012), “Consumer acceptance and use of information technology: extending the unified theory of acceptance and use of technology", MIS Quarterly, Vol. 36 No. 1, pp. 157-178.

Vivek, S. D., Beatty, S. E. and Morgan, R. M. (2012), “Customer engagement: Exploring customer relationships beyond purchase”, Journal of Marketing Theory and Practice, Vol. 20 No. 2, pp. 122-146.

World Bank. (2018), "Financial inclusion on the rise, but gaps remain, global Findex Database Shows", available at: https://www.worldbank.org/en/news/pressrelease/2018/04/19/financial-inclusion-on-the-rise-but-gaps-remain-global-findex-databaseshows (accessed 20 November, 2018).

Zhou, T., Lu, Y. and Wang, B. (2010), “Integrating TTF and UTAUT to explain mobile banking user adoption”, Computers in Human Behavior, Vol. 26 No. 4, pp. 760-767. 


\section{List of Figures}

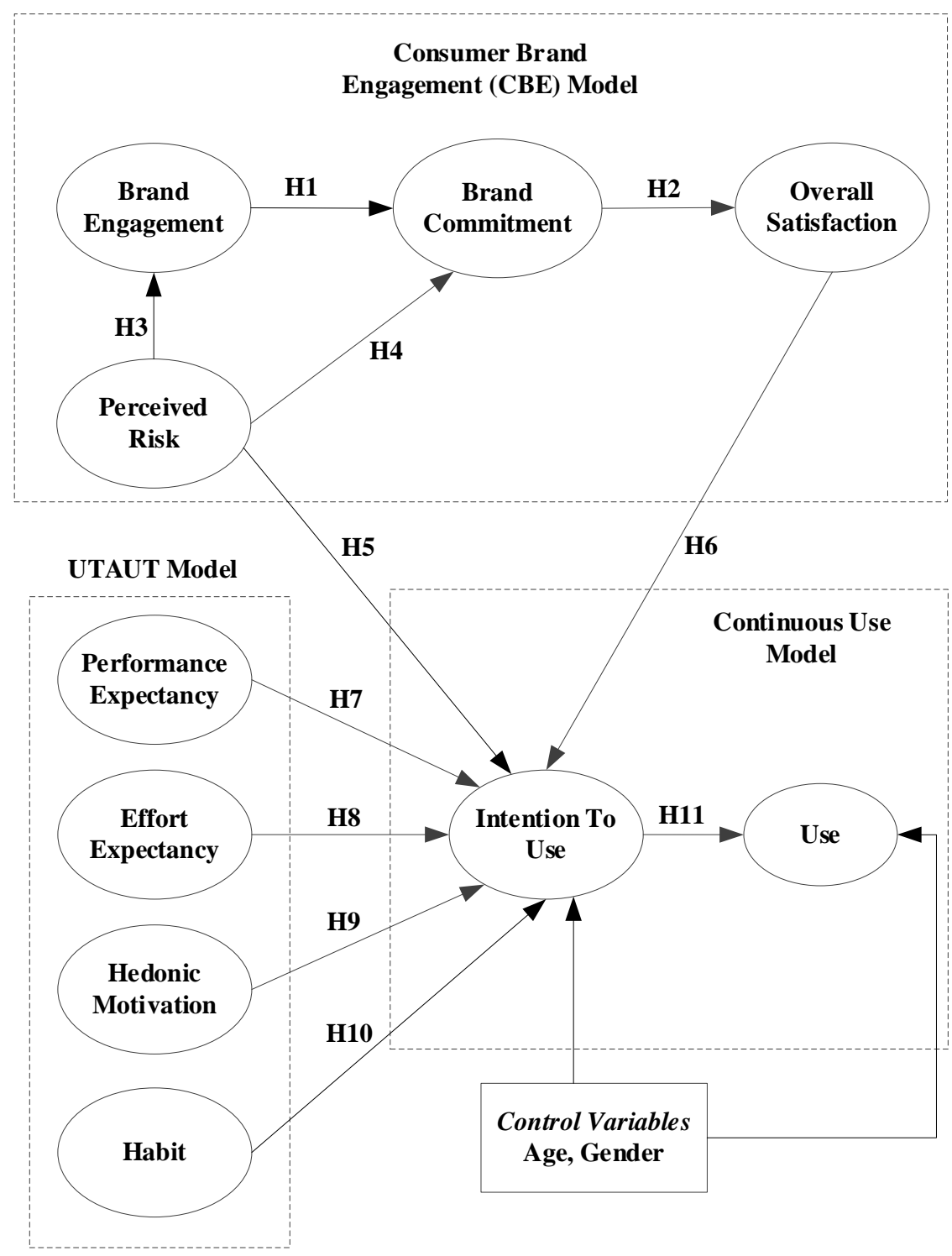

FIGURE 1: Research Model 

FIGURE 2: Path Model

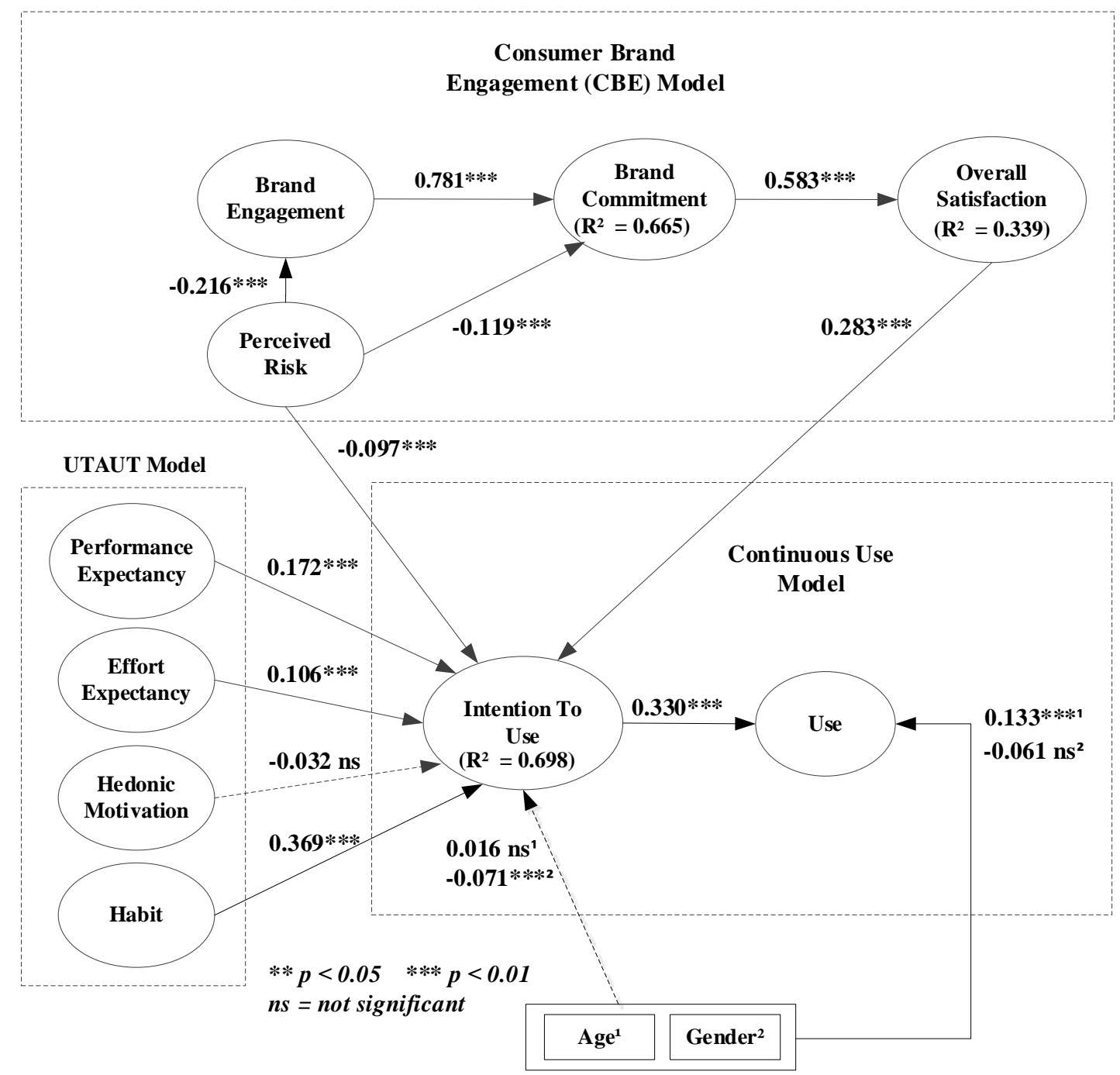




\section{List of Tables}

Table 1. Average variance explained (AVE), Composite reliability, construct correlations, square roots of AVE (diagonal), Means, and Standard Deviations

\begin{tabular}{|c|c|c|c|c|c|c|c|c|c|c|c|c|c|c|c|c|c|c|c|}
\hline Construct & AVE & $\mathrm{CR}^{\mathrm{t}}$ & (1) & (2) & (3) & (4) & (5) & (6) & (7) & (8) & (9) & (10) & (11) & (12) & (13) & (14) & (15) & (16) & (17) \\
\hline RIS (1) & 0.714 & 0.926 & 0.845 & & & & & & & & & & & & & & & & \\
\hline $\mathrm{CBE}(2)^{\mathrm{b}}$ & $\mathrm{n} / \mathrm{a}^{\mathrm{r}}$ & $n / a^{r}$ & -0.218 & $n / a^{r}$ & & & & & & & & & & & & & & & \\
\hline CENG $(3)^{c}$ & 0.666 & 0.857 & -0.035 & 0.666 & 0.816 & & & & & & & & & & & & & & \\
\hline AENG (4) ${ }^{\mathrm{d}}$ & 0.824 & 0.933 & -0.232 & 0.951 & 0.555 & 0.908 & & & & & & & & & & & & & \\
\hline BENG (5) ${ }^{\mathrm{e}}$ & 0.888 & 0.941 & -0.114 & 0.501 & 0.157 & 0.267 & 0.942 & & & & & & & & & & & & \\
\hline $\operatorname{PE}(6)^{f}$ & 0.634 & 0.874 & -0.364 & 0.560 & 0.369 & 0.593 & 0.126 & 0.796 & & & & & & & & & & & \\
\hline $\operatorname{EE}(7)^{g}$ & 0.742 & 0.920 & -0.395 & 0.347 & 0.128 & 0.351 & 0.168 & 0.443 & 0.861 & & & & & & & & & & \\
\hline $\mathrm{HM}(8)^{\mathrm{h}}$ & 0.861 & 0.949 & -0.300 & 0.635 & 0.409 & 0.672 & 0.147 & 0.636 & 0.451 & 0.928 & & & & & & & & & \\
\hline HAB (9) ${ }^{\mathrm{i}}$ & 0.583 & 0.841 & -0.357 & 0.417 & 0.229 & 0.473 & 0.039 & 0.678 & 0.478 & 0.566 & 0.763 & & & & & & & & \\
\hline COM $(10)^{j}$ & 0.605 & 0.902 & -0.290 & 0.807 & 0.535 & 0.764 & 0.402 & 0.551 & 0.456 & 0.564 & 0.402 & 0.778 & & & & & & & \\
\hline $\operatorname{SAT}(11)^{k}$ & 0.862 & 0.949 & -0.486 & 0.498 & 0.216 & 0.519 & 0.183 & 0.619 & 0.723 & 0.552 & 0.650 & 0.583 & 0.929 & & & & & & \\
\hline INT (12) ${ }^{1}$ & 0.799 & 0.923 & -0.470 & 0.412 & 0.208 & 0.442 & 0.103 & 0.664 & 0.587 & 0.517 & 0.743 & 0.465 & 0.735 & 0.894 & & & & & \\
\hline USE1 (13) $)^{\mathrm{m}}$ & $\mathrm{n} / \mathrm{a}^{\mathrm{s}}$ & $\mathrm{n} / \mathrm{a}^{\mathrm{s}}$ & -0.112 & 0.318 & 0.164 & 0.233 & 0.402 & 0.273 & 0.164 & 0.154 & 0.281 & 0.338 & 0.249 & 0.212 & $\mathbf{n} / \mathbf{a}$ & & & & \\
\hline USE2 $(14)^{\mathrm{n}}$ & $\mathrm{n} / \mathrm{a}^{\mathrm{s}}$ & $\mathrm{n} / \mathrm{a}^{\mathrm{s}}$ & -0.097 & 0.074 & 0.023 & 0.063 & 0.081 & 0.091 & 0.039 & 0.081 & 0.159 & 0.062 & 0.070 & 0.120 & -0.270 & $\mathbf{n} / \mathbf{a}$ & & & \\
\hline USE3 (15) ${ }^{\circ}$ & $\mathrm{n} / \mathrm{a}^{\mathrm{s}}$ & $\mathrm{n} / \mathrm{a}^{\mathrm{s}}$ & -0.012 & -0.081 & 0.026 & 0.014 & -0.371 & 0.131 & 0.084 & 0.081 & 0.228 & -0.043 & 0.100 & 0.201 & -0.058 & 0.061 & $\mathbf{n} / \mathbf{a}$ & & \\
\hline GEN (16) ${ }^{\mathrm{p}}$ & $\mathrm{n} / \mathrm{a}^{\mathrm{s}}$ & $\mathrm{n} / \mathrm{a}^{\mathrm{s}}$ & 0.098 & -0.001 & 0.018 & 0.003 & -0.044 & -0.092 & -0.019 & 0.001 & -0.102 & -0.048 & -0.021 & -0.144 & -0.016 & -0.179 & -0.014 & $\mathbf{n} / \mathbf{a}$ & \\
\hline AGE (17) & $\mathrm{n} / \mathrm{a}^{\mathrm{s}}$ & $\mathrm{n} / \mathrm{a}^{\mathrm{s}}$ & -0.144 & -0.020 & 0.026 & -0.078 & 0.128 & -0.058 & -0.047 & -0.121 & -0.002 & 0.046 & -0.001 & 0.027 & 0.178 & 0.036 & -0.055 & -0.141 & $\mathbf{n} / \mathbf{a}$ \\
\hline Mean & & & 2.54 & 3.92 & 3.70 & 3.77 & 4.30 & 4.48 & 6.05 & 4.63 & 3.39 & 6.39 & 5.74 & 5.34 & 3.20 & 2.02 & 2.55 & $\mathrm{n} / \mathrm{a}$ & $\mathrm{n} / \mathrm{a}$ \\
\hline S.D. ${ }^{q}$ & & & 1.42 & 1.84 & 1.70 & 1.64 & 2.35 & 1.66 & 1.21 & 1.70 & 1.70 & 2.37 & 1.51 & 1.62 & 1.83 & 1.72 & 2.18 & $\mathrm{n} / \mathrm{a}$ & $\mathrm{n} / \mathrm{a}$ \\
\hline
\end{tabular}

Notes:

${ }^{\mathrm{a}}$ RIS - Perceived risk; b CBE - Consumer brand engagement; ${ }^{\mathrm{c}} \mathrm{CENG}$ - Cognitive brand engagement; ${ }^{\mathrm{d}}$ AENG - Affective brand engagement; ${ }^{\mathrm{e}} \mathrm{BENG}$ - Behavioral brand engagement; ${ }^{\mathrm{f}} \mathrm{PE}$ - Performance expectancy; ${ }^{\mathrm{g}} \mathrm{EE}$ - Effort expectancy; ${ }^{\mathrm{h}} \mathrm{HM}$ - Hedonic motivation; ${ }^{\mathrm{i}} \mathrm{HAB}$ - Habit; ${ }^{\mathrm{j}} \mathrm{COM}$ - Brand commitment; ${ }^{\mathrm{k}} \mathrm{SAT}$ - Overall satisfaction; ${ }^{1}$ INT - Behavioral intention; ${ }^{\mathrm{m}}$ USE1 - Use m-wallet; ${ }^{\mathrm{n}}$ USE2 - Use NFC; ${ }^{\circ}$ USE3 - Use card's contactless payment function; ${ }^{\mathrm{p}}$ GEN - Gender q S.D. - Standard Deviation

${ }^{\mathrm{r}} \mathrm{n} / \mathrm{a}$ - not applicable. $2^{\text {nd }}$ order formative construct, AVE and CR cannot be computed.

${ }^{\mathrm{s}} \mathrm{n} / \mathrm{a}-$ not applicable. Single items. AVE and CR cannot be computed.

${ }^{\mathrm{t}} \mathrm{CR}$ - Composite Reliability 
Perceived risk (If using contactless payments...)

$\begin{array}{ll}\begin{array}{c}\text { Factor } \\ \text { loading }\end{array} & \text { Mean } \\ & \\ 0.832 * * * & 2.87 \\ & \\ & \\ 0.871^{* * *} & 2.64 \\ 0.864 * * * & 2.30 \\ 0.790^{* * *} & 2.39 \\ 0.864 * * * & 2.49\end{array}$

On the whole, considering all sorts of factors combined, about how risky would you say it would be to sign up for and use contactless payments? (1=Not risky at all...7=very risky)

Using contactless payments to pay my bills would be risky.

Contactless payments are dangerous to use.

Using contactless payments would add great uncertainty to my bill paying.

Using contactless payments exposes you to overall risk.

(1=Improbable...7=probable)

\section{Brand engagement ( $1^{\text {st }}$ order reflective constructs)}

Cognitive

Using X (Contactless Payment Brand) gets me to think about X (Contactless

Payment Brand).

I think about X (Contactless Payment Brand) a lot when I'm using it.

$0.814 * * *$

Using X (Contactless Payment Brand) stimulates my interest to learn more

$0.846 * * *$

about X (Contactless Payment Brand).

Affective

Using X (Contactless Payment Brand) makes me happy.

I feel good when I use X (Contactless Payment Brand).

$0.893 * * * \quad 4.23$

I'm proud to use X (Contactless Payment Brand).

$0.916 * * * \quad 3.43$

Behavioural

I spend a lot of time using X (Contactless Payment Brand) compared to other

$0.914^{* * *}$

contactless payment providers.

Whenever I'm using X (Contactless Payment Brand), I usually use X

$0.946^{* * *}$

(Contactless Payment Brand).

$\mathrm{X}$ (Contactless Payment Brand) is one of the brands I usually use when I use

$0.939 * * *$ contactless payment (item dropped)

Brand engagement ( $2^{\text {nd }}$ order formative construct)

Cognitive

$0.196 * * *$ a $\quad 3.70$

Affective

$0.772 * * *$ a $\quad 3.77$

Behavioral

$0.264 * * *$ a $\quad 4.30$

\section{Brand commitment}

I take pleasure in being a customer of X (Contactless Payment Brand).

$0.830 * * * \quad 7.12$

$\mathrm{X}$ (Contactless Payment Brand) is the provider that takes the best care of its customers.

I get back what I put into my relationship with X (Contactless Payment Brand). My attachment to X (Contactless Payment Brand) is mainly based on the similarity if our values.

Because of the values X (Contactless Payment Brand) stands for, being a

\section{Overall satisfaction}

Overall, how satisfied are you with contactless payments (1=extremely dissatisfied...5=extremely satisfied)

I am very satisfied with contactless payments (1=strongly

disagree...10=strongly agree)

What kind of experiences you have from contactless payments? (1=very poor...7=Very good)

\section{Performance expectancy}


Using contactless payments increases my chances of achieving things that are important to me.

Using contactless payments helps me to accomplish things more quickly.

\section{Effort expectancy}

Learning how to use contactless payments is easy for me.

My interaction with contactless payments is clear and understandable.

I find contactless payments easy to use.

It is easy for me to become skilful at using contactless payments.

\section{Hedonic motivation}

Using contactless payments is fun.

Using contactless payments is enjoyable.

\section{Habit}

The use of contactless payments has become a habit for me.

I must use contactless payments.

\section{Intention to use}

I intend to continue using contactless payments in the future.

Use - Formative Construct (How often you use the following contactless payment formats?) (1=Never...7=Daily)

Mobile wallet offered by my mobile operator (sticker on the phone) $\quad 0.860^{\text {b }} \quad 3.20$

$\begin{array}{lll}\text { NFC on the mobile phone } & 0.597^{\mathrm{b}} & 2.02\end{array}$

\begin{tabular}{lll} 
Bank card's contactless payment function & $0.4399^{\mathrm{b}}$ & 2.55 \\
\hline
\end{tabular}

Notes:

Scales are ranging from “1=strongly disagree”...”7=Strongly agree” (if not otherwise mentioned)

a Formative construct's measurement loadings

${ }^{\mathrm{b}}$ Weights

*** $p<0.001$ 
Table 3. Hypotheses testing

H1: Consumer brand engagement $\rightarrow$ Brand commitment

\begin{tabular}{|c|c|}
\hline$\beta$ & Hypotheses test \\
\hline $0.781^{* * *}$ & Supported \\
\hline $0.583 * * *$ & Supported \\
\hline$-0.216 * * *$ & Supported \\
\hline$-0.119 * * *$ & Supported \\
\hline$-0.097 * * *$ & Supported \\
\hline $0.283^{* * *}$ & Supported \\
\hline $0.172 * * *$ & Supported \\
\hline $0.106 * * *$ & Supported \\
\hline-0.032 (ns) & Rejected \\
\hline $0.369 * * *$ & Supported \\
\hline $0.330 * * *$ & Supported \\
\hline 0.016 (ns) & $\mathrm{n} / \mathrm{a}^{1}$ \\
\hline $0.133 * * *$ & $\mathrm{n} / \mathrm{a}^{1}$ \\
\hline$-0.071 * * *$ & $\mathrm{n} / \mathrm{a}^{1}$ \\
\hline-0.061 (ns) & $\mathrm{n} / \mathrm{a}^{1}$ \\
\hline$R^{2}$ & \\
\hline 0.665 & \\
\hline 0.339 & \\
\hline 0.698 & \\
\hline
\end{tabular}

H2: Brand commitment $\rightarrow$ Overall satisfaction

H3: Perceived risk $\rightarrow$ Consumer brand engagement

H4: Perceived risk $\rightarrow$ Brand commitment

H5: Perceived risk $\rightarrow$ Intention to use

H6: Overall satisfaction $\rightarrow$ Intention to use

H7: Performance expectancy $\rightarrow$ Intention to use

H8: Effort expectancy $\rightarrow$ Intention to use

H9: Hedonic motivation $\rightarrow$ Intention to use

H10: Habit $\rightarrow$ Intention to use

H11: Intention to use $\rightarrow$ Use

Age $\rightarrow$ Intention to use

Age $\rightarrow$ Use

Gender $\rightarrow$ Intention to use

Gender $\rightarrow$ Use

$R^{2}$

Brand commitment

Intention to use

Notes:

** $p<0.05$; *** $p<0.01$, ns - not significant

${ }^{1} \mathrm{n} / \mathrm{a}$ - Not applicable. Gender and age are control variables. 